\title{
THE DIGITAL BLOOD FLOW, ARTERIAL PRESSURE, AND \\ VASCULAR RESISTANCE IN ARTERIAL HYPERTEN- SION AND IN CORONARY THROMBOSIS
}

\author{
By MILTON MENDLOWITZ \\ (From the Medical Services of the Mount Sinai Hospital, New York)
}

(Received for publication April 2, 1942)

Methods for the measurement of the digital blood pressure and flow have been described in a previous report (1). The calculation of the blood flow from calorimetric observations has since been modified, and a method developed for calculating the digital vascular resistance. With these methods, studies have been made on normal subjects and on patients with various types of hypertension. Since a decrease in cardiac output had been found after coronary artery ligation in dogs (2), investigations were also made on patients with coronary occlusion in order to determine whether a consistent change in the digital circulation could be demonstrated.

\section{METHOD}

All measurements were made under standardized conditions. The patient was resting in bed and the measurements were made after warming the body, by placing one arm in water at a temperature of from $43^{\circ}$ to $45^{\circ} \mathrm{C}$. until sweating became generalized. After this procedure, reproducible digital blood flow measurements are obtainable in the same individual, whether normal or abnormal. Whether the degree of vasodilatation thus obtained represents a complete release of sympathetic tone, however, is still controversial.

The digital blood flow was measured by the calorimetric method (1). According to Stewart (3), the specific heat of normal blood is nearer 0.9 than 1.0. The specific heat of tissue, on the other hand, is approximately 0.8 . The accuracy of the method was therefore slightly increased by substituting 0.9 for 1.0 as the specific heat of the blood, and by adding the hydrothermic equivalent of the immersed finger tip (volume multiplied by 0.8 ) to the other hydrothermic equivalents.

The exact relationships between blood flow, blood pressure, blood viscosity, and frictional resistance of the vascular bed have not yet been clearly delineated. For practical purposes, however, the relationships proposed by Böger and Wezler (4) and by Bazett, Cotton, Laplace and Scott (5) may be applied to the digital circulation. According to these workers, if $F$ is the blood flow, $P$, the effective mean arterial pressure, and $R$, the so-called peripheral vascular resistance, then,

$\begin{array}{ll}\text { and } & F \propto P ; \\ \text { hence, } & F \propto \frac{1}{R} ; \\ \text { and } & F=\frac{P}{R} K ; \\ & R=\frac{P}{F} K\end{array}$

On close analysis, $\mathrm{R}$ depends chiefly on the size of the vascular bed and on the viscosity of the blood. It has been shown that the effective viscosity varies very little with erythrocyte concentrations in the normal range of variation (6). Since our measurements were made upon patients whose erythrocyte counts varied from four to five million per c. mm., the viscosity factor may be assumed to be relatively fixed and variations in $R$ to be caused chiefly by variations in the size of the vascular bed, especially the cross-sectional area.

In determining the peripheral vascular resistance, $R$, of the entire systemic circulation, Bazett, Cotton, Laplace and Scott (5) assigned an arbitrary value of 3.0 to $K$ in order to bring the normal units of resistance approximately to 100 . The corresponding value for $K$ in the digital circulation is 0.3 , since $F$ is expressed in cc. per sq. cm. per minute, instead of in liters per sq. meter per minute. Until the exact physical relationships governing the peripheral circulation are worked out, such arbitrary units are preferable, for comparative measurements, to the physical units proposed by Böger and Wezler (4).

The digital vascular resistance, $R$, therefore, is calculated from the equation,

$$
R=\frac{P}{F} K .
$$

The value for $K$ is $0: 3 . \quad F$ is the digital blood flow in cc. per sq. $\mathrm{cm}$. per minute as measured by the calorimetric method. $P$ is the effective mean digital arterial pressure which is obtained by subtracting the venous pressure from the arithmetic mean of digital systolic and diastolic pressures, as measured with the Gaertner capsule $(7,8)$. For practical purposes the arithmetic mean is an adequate approximation of the true mean arterial pressure. The venous pressure is arbitrarily assumed to be $6 \mathrm{~mm}$. of mercury in the absence of congestive heart failure. In many of the cases of coronary thrombosis, the actual ante- 
cubital venous pressure was determined by the direct method and in most, found to be normal. In the occasional case in which it was found elevated, the actual value was substituted for $6 \mathrm{~mm}$. Since measurements of digital arterial pressure were made approximately at heart level, the hydrostatic factor could be disregarded.

Twelve normal subjects, thirty patients with various types of hypertension, and twenty-six cases of coronary occlusion, were studied with these methods. Many of the patients with coronary occlusion had preëxisting hypertension. In some, the antecedent hypertension was verifiable from previous records or from the history, whereas in the remainder, the previous blood pressures were either normal or unknown.

\section{RESULTS}

\section{Normal subjects}

The results in twelve normal subjects are presented in Table I. With the new modifications in method, the normal range of variation in digital blood flow was from 0.23 to $0.34 \mathrm{cc}$. per sq. $\mathrm{cm}$.

TABLE I

Normal

\begin{tabular}{|c|c|c|c|c|c|c|}
\hline \multirow[b]{2}{*}{ Patient } & \multirow[b]{2}{*}{$\begin{array}{l}\text { Age } \\
\text { and } \\
\text { sex }\end{array}$} & \multirow[b]{2}{*}{$\begin{array}{c}\text { Pre- } \\
\text { liminary } \\
\text { brachial } \\
\text { blood } \\
\text { pressure }\end{array}$} & \multicolumn{4}{|c|}{ After body warming } \\
\hline & & & $\begin{array}{c}\text { Brachial } \\
\text { blood } \\
\text { pressure }\end{array}$ & $\begin{array}{l}\text { Digital } \\
\text { blood } \\
\text { pressure }\end{array}$ & $\begin{array}{l}\text { Digital } \\
\text { blood } \\
\text { flow }\end{array}$ & $\begin{array}{l}\text { Digital } \\
\text { vascu- } \\
\text { lar re- } \\
\text { sist- } \\
\text { ance }\end{array}$ \\
\hline & & $m m . H g$ & $m m . \mathrm{Hg}$ & mm. $\mathrm{Hg}$ & $\begin{array}{c}\text { cc. per } \\
\text { sq.cm. per } \\
\text { minute }\end{array}$ & units \\
\hline $\begin{array}{l}\text { P. W. } \\
\text { A. S. H. } \\
\text { A. R. } \\
\text { W. P. } \\
\text { A. F. M. } \\
\text { A. L. } \\
\text { A. M. } \\
\text { M. M. } \\
\text { A. K. } \\
\text { P. S. C. } \\
\text { G. J. C. } \\
\text { M. C. M. }\end{array}$ & $\begin{array}{ll}22 & M \\
31 & M \\
25 & M \\
23 & M \\
30 & M \\
24 & M \\
45 & M \\
31 & M \\
50 & M \\
45 & F \\
51 & M \\
25 & F\end{array}$ & $\begin{array}{l}110 / 75 \\
125 / 86 \\
118 / 88 \\
120 / 85 \\
122 / 84 \\
118 / 75 \\
112 / 75 \\
125 / 84 \\
122 / 86 \\
102 / 72 \\
130 / 85 \\
110 / 72\end{array}$ & $\begin{array}{l}102 / 74 \\
130 / 85 \\
112 / 82 \\
118 / 85 \\
118 / 90 \\
108 / 74 \\
114 / 72 \\
115 / 86 \\
105 / 72 \\
104 / 68 \\
125 / 78 \\
104 / 74\end{array}$ & $\begin{array}{r}88 / 40 \\
106 / 50 \\
84 / 70 \\
102 / 64 \\
96 / 60 \\
104 / 64 \\
108 / 68 \\
98 / 55 \\
86 / 60 \\
96 / 64 \\
108 / 70 \\
88 / 50\end{array}$ & $\begin{array}{l}0.27 \\
0.23 \\
0.31 \\
0.24 \\
0.34 \\
0.31 \\
0.32 \\
0.31 \\
0.33 \\
0.30 \\
0.31 \\
0.26\end{array}$ & $\begin{array}{l}63 \\
93 \\
69 \\
96 \\
63 \\
75 \\
75 \\
69 \\
61 \\
75 \\
81 \\
72\end{array}$ \\
\hline
\end{tabular}

per minute. The average was $0.29 \mathrm{cc}$. \pm a standard deviation of $0.03 \mathrm{cc}$. The average arithmetic mean digital arterial pressure was $78 \mathrm{~mm}$. of mercury \pm a standard deviation of $7 \mathrm{~mm}$. The average arithmetic mean brachial arterial pressure was $96 \mathrm{~mm}$. of mercury \pm a standard deviation of 7 $\mathrm{mm}$. The average digital vascular resistance was
74 units \pm a standard deviation of 11 units. The normal range of variation was from 63 to 96 units.

\section{Arterial hypertension}

The results in thirty cases of hypertension are presented in Table II. Eight apparently normal subjects had elevated blood pressure before body warming. In these cases, the hypertension may be called neurogenic since it subsided after body warming, no increase in fixed resistance being demonstrable. In two of these cases (J. J. and L. L.), the vascular resistance was on the borderline, and it was impossible to be sure that these patients did not have early fixed hypertension. In one case of pheochromocytoma, the elevated preliminary blood pressure subsided promptly after warming the body and no increase in fixed resistance could be demonstrated.

In three cases of early essential hypertension in young people, the blood flow was definitely below the lower limit of normal and the resistance elevated out of proportion to the rise in blood pressure. Similar observations were made in three cases of acute glomerulonephritis. In two of these cases the increase in resistance was reversible, since both the blood flows and blood pressures became normal after the nephritis subsided.

In nine cases of essential hypertension of several years duration, in one case of chronic glomerulonephritis, and in one case of toxemia of pregnancy, the digital blood flows were within normal limits, and the resistances elevated in proportion to the blood pressure levels. In several of these cases, there was a superimposed complement of neurogenic hypertension, since the preliminary blood pressures dropped to less elevated levels after warming the body.

In three of the four cases of malignant hypertension, the digital blood flow was decreased and in the fourth, it was at the lower limit of normal. In these cases, the digital vascular resistance was elevated out of proportion to the increase in blood pressure.

\section{Coronary occlusion}

The results in twenty-six cases of coronary occlusion are presented in Table III. In ten of the cases of acute myocardial infarction, both the clin- 
TABLE II

Hypertension

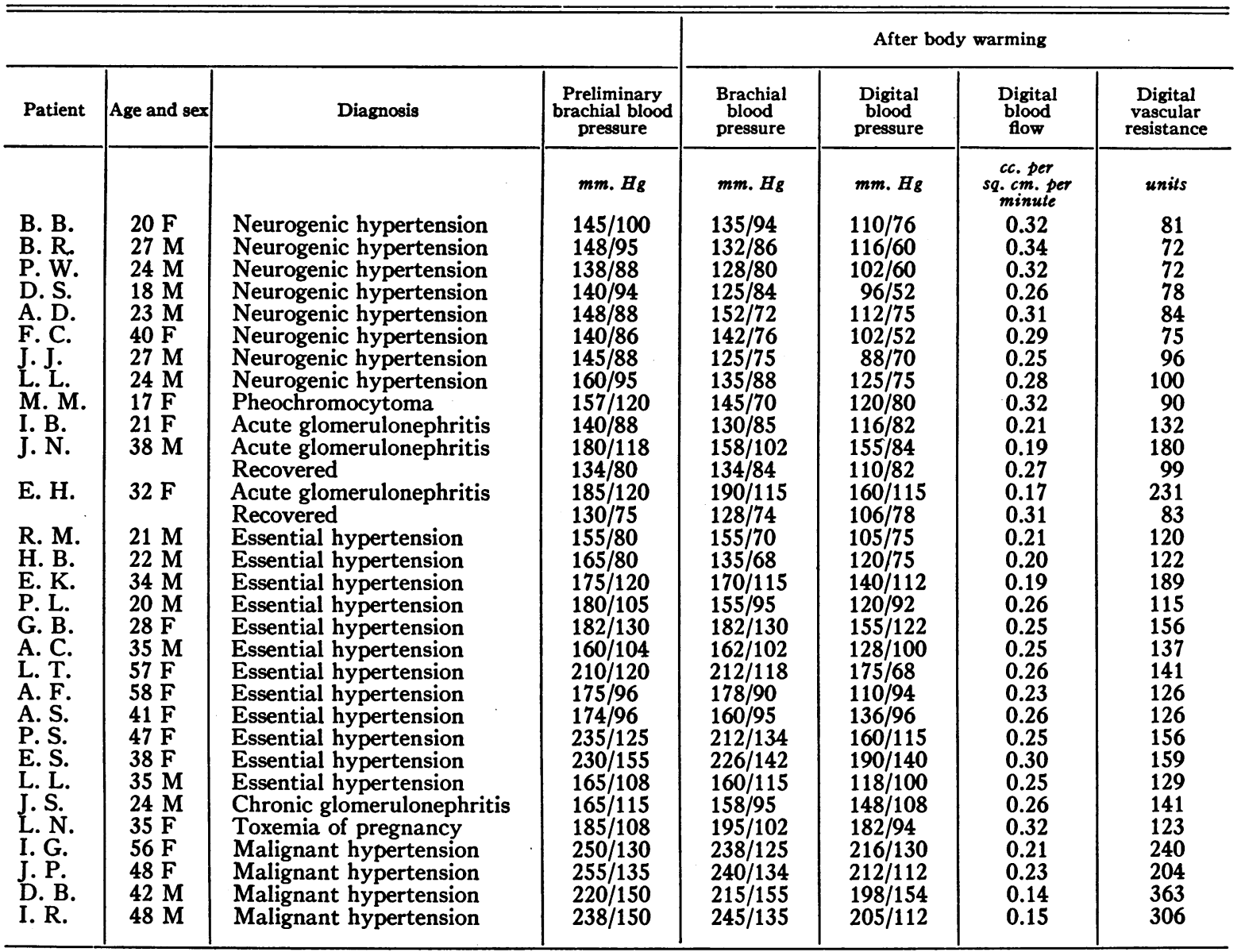

ical course and the electrocardiographic changes were typical. In nine of these cases the digital blood flow was below the lower limit of normal and in the remaining case, within the normal range.

In five cases of acute myocardial infarction, the clinical course of the disease was characteristic but the electrocardiographic findings were equivocal, either because the patient was seen several weeks after the onset of symptoms, or because of associated electrocardiographic changes, such as intra-ventricular block. In each of these cases, the digital blood flow was below the lower limit of normal.

In five cases, the clinical course was atypical despite progressive changes in the electrocardio- gram. No definite diagnosis could be made in these cases although they were suggestive of either coronary occlusion or coronary insufficiency. The digital blood flow was found to be decreased in three of these cases and normal in two.

In three cases of coronary occlusion, studied several months or more after the acute attack, the digital blood flow was normal in all three.

No cases of acute coronary occlusion were studied in the first few days after the onset of symptoms, when the blood pressure is said to rise in some cases because of compensatory vasoconstriction (9). In the more stabilized phase in which these cases were studied, the digital vascular resistance was generally in accord with the level of the blood pressure prior to the acute at- 
TABL II

Coronary occlusion

\begin{tabular}{|c|c|c|c|c|c|c|c|c|c|c|c|}
\hline \multirow[b]{2}{*}{ Patient } & \multirow{2}{*}{$\begin{array}{l}\text { Age } \\
\text { and } \\
\text { Bex }\end{array}$} & \multirow{2}{*}{$\begin{array}{l}\text { Clinical } \\
\text { oourse }\end{array}$} & \multirow[b]{2}{*}{$\begin{array}{l}\text { Electro- } \\
\text { oardiogram }\end{array}$} & \multirow[b]{2}{*}{$\begin{array}{l}\text { Date of onset } \\
\text { of symptoms }\end{array}$} & \multirow{2}{*}{$\begin{array}{l}\text { Date of } \\
\text { observations }\end{array}$} & \multirow{2}{*}{$\begin{array}{l}\text { Previous } \\
\text { brachial } \\
\text { blood } \\
\text { pressure }\end{array}$} & \multirow{2}{*}{$\begin{array}{c}\text { Pre- } \\
\text { liminary } \\
\text { brachial } \\
\text { blood } \\
\text { pressure }\end{array}$} & \multicolumn{4}{|c|}{ After body warming } \\
\hline & & & & & & & & $\begin{array}{l}\text { Braohial } \\
\text { blood } \\
\text { pressure }\end{array}$ & $\begin{array}{l}\text { Digital } \\
\text { blood } \\
\text { pressure }\end{array}$ & $\begin{array}{l}\text { Digital } \\
\text { blood } \\
\text { flow }\end{array}$ & $\begin{array}{l}\text { Digital } \\
\text { vascu- } \\
\text { lar re- } \\
\text { sistance }\end{array}$ \\
\hline B.8. & $55 \mathbf{M}$ & $\begin{array}{l}\text { Typical; second } \\
\text { attack }\end{array}$ & Progreasive ohange & May 19, 1941 & June 6, 1941 & $\begin{array}{l}\text { mm. } \mathrm{Hg} \\
230 / ?\end{array}$ & $\begin{array}{l}m m . H g \\
142 / 90\end{array}$ & $\begin{array}{l}\text { mm. } H_{g} \\
130 / 86\end{array}$ & $\begin{array}{l}m m . H g \\
130 / 85\end{array}$ & $\begin{array}{l}\text { cc. per } \\
\text { eq. cm. } \\
\text { per min. } \\
0.13\end{array}$ & $\begin{array}{l}\text { units } \\
234\end{array}$ \\
\hline $\begin{array}{l}\text { B.M. } \\
\text { B.P. } \\
\text { E.S. } \\
\text { A.O. } \\
\text { B.W. } \\
\text { J.K. } \\
\text { A.B. } \\
\text { H.M. } \\
\text { N.A. }\end{array}$ & $\begin{array}{l}63 \mathrm{M} \\
52 \mathrm{~F} \\
48 \mathrm{~F} \\
52 \mathrm{M} \\
59 \mathrm{M} \\
47 \mathrm{M} \\
60 \mathrm{~F} \\
63 \mathrm{M} \\
62 \mathrm{M}\end{array}$ & $\begin{array}{l}\text { Typical } \\
\text { Typical } \\
\text { Typical } \\
\text { Typical } \\
\text { Typical } \\
\text { Typiosal } \\
\text { Typical } \\
\text { Typical } \\
\text { Typical; second }\end{array}$ & $\begin{array}{l}\text { Progreaive ohange } \\
\text { Progreasive change } \\
\text { Progreasive ohange } \\
\text { Progreasive ohange } \\
\text { Progreagive change } \\
\text { Progreasive change } \\
\text { Progreasive change } \\
\text { Progreasive change } \\
\text { Progreasive ohange }\end{array}$ & $\begin{array}{l}\text { May 13, } 1941 \\
\text { July 2, 1941 } \\
\text { July 25, 1941 } \\
\text { August 19, 1941 } \\
\text { September 2, 1941 } \\
\text { September 8, 1941 } \\
\text { September 30, 1941 } \\
\text { November 22, 1941 } \\
\text { October 12, 1941 }\end{array}$ & $\begin{array}{l}\text { June 20, } 1941 \\
\text { Auguat 4, } 1941 \\
\text { August 23, } 1941 \\
\text { Soptember 19, 1941 } \\
\text { September 30, } 1941 \\
\text { Ootober 8, 1941 } \\
\text { Ootober 25, 1941 } \\
\text { December 6, } 1941 \\
\text { November 16, } 1941\end{array}$ & $\begin{array}{l}\text { Unknown } \\
\text { High } \\
200 / 9 \\
140 / 96 \\
\text { Unknown } \\
132 / 92 \\
\text { Unknown } \\
\text { Unknown } \\
\text { Normal }\end{array}$ & $\begin{array}{l}120 / 88 \\
126 / 80 \\
160 / 102 \\
118 / 84 \\
135 / 95 \\
116 / 72 \\
105 / 85 \\
116 / 78 \\
100 / 72\end{array}$ & $\begin{array}{l}112 / 85 \\
126 / 90 \\
164 / 102 \\
116 / 76 \\
108 / 82 \\
110 / 74 \\
88 / 68 \\
118 / 76 \\
98 / 74\end{array}$ & $\begin{array}{c}88 / 72 \\
118 / 102 \\
140 / 78 \\
110 / 76 \\
98 / 68 \\
102 / 64 \\
72 / 60 \\
100 / 64 \\
70 / 48\end{array}$ & $\begin{array}{l}0.22 \\
0.27 \\
0.18 \\
0.14 \\
0.12 \\
0.16 \\
0.20 \\
0.18 \\
0.16\end{array}$ & $\begin{array}{r}102 \\
117 \\
180 \\
186 \\
192 \\
144 \\
90 \\
127 \\
99\end{array}$ \\
\hline B.I. & $55 \mathrm{~F}$ & Typical; recond & Equirocal & July 9, 1941 & July 23, 1941 & $190 / ?$ & $138 / 100$ & $138 / 94$ & $125 / 86$ & 0.17 & 177 \\
\hline $\begin{array}{l}\text { M.N. } \\
\text { A.G. } \\
\text { B.D. } \\
\text { P.N. } \\
\text { R.S. } \\
\text { G.I. } \\
\text { M.H. } \\
\text { M.M. } \\
\text { B.B. } \\
\text { B.V. }\end{array}$ & $\begin{array}{l}50 \mathrm{~F} \\
67 \mathrm{M} \\
63 \mathrm{M} \\
43 \mathrm{M} \\
58 \mathrm{~F} \\
58 \mathrm{~F} \\
40 \mathrm{~F} \\
65 \mathrm{~F} \\
52 \mathrm{~F} \\
63 \mathrm{M}\end{array}$ & $\begin{array}{l}\text { Typical } \\
\text { Typical } \\
\text { Typical } \\
\text { Typical } \\
\text { Atypical } \\
\text { Atypical } \\
\text { Atypical } \\
\text { Atypical } \\
\text { Atypical } \\
\text { Atypical; } 8000 \text { d }\end{array}$ & $\begin{array}{l}\text { Equivocal } \\
\text { Equivocal } \\
\text { Equivocal } \\
\text { Equivoogl } \\
\text { Progresive change } \\
\text { Progreaive ohange } \\
\text { Progresaive change } \\
\text { Progresive change } \\
\text { Progreedve ohange } \\
\text { Equivocal }\end{array}$ & $\begin{array}{l}\text { August 9, } 1941 \\
\text { August 27, 1941 } \\
\text { Ootober 24, 1941 } \\
\text { November 8, } 1941 \\
\text { May 9, 1941 } \\
\text { July 9, 1941 } \\
\text { November 17, } 1941 \\
\text { November 27, } 1941 \\
\text { December 4. 1941 } \\
\text { Ootober 2, 1941 }\end{array}$ & $\begin{array}{l}\text { September 18, } 1941 \\
\text { Ootober 2, 1941 } \\
\text { November 17, } 1941 \\
\text { November 17, } 1941 \\
\text { June 10, 1941 } \\
\text { August 1, 1941 } \\
\text { November 29, } 1941 \\
\text { December 10, } 1941 \\
\text { December 20, } 1941 \\
\text { October 31, } 1941\end{array}$ & $\begin{array}{l}160 / 110 \\
\text { Unknown } \\
150 / 80 \\
\text { Unknown } \\
180 / 9 \\
180 / 9 \\
\text { High } \\
\text { High } \\
190 / 85 \\
180 / 100\end{array}$ & $\begin{array}{l}125 / 88 \\
120 / 90 \\
135 / 65 \\
135 / 90 \\
160 / 80 \\
165 / 75 \\
150 / 92 \\
155 / 68 \\
158 / 88 \\
150 / 84\end{array}$ & $\begin{array}{l}128 / 88 \\
98 / 76 \\
124 / 68 \\
116 / 74 \\
150 / 85 \\
145 / 72 \\
138 / 76 \\
142 / 50 \\
148 / 78 \\
150 / 85\end{array}$ & $\begin{array}{r}104 / 90 \\
96 / 60 \\
106 / 64 \\
88 / 70 \\
118 / 92 \\
102 / 70 \\
108 / 74 \\
96 / 72 \\
124 / 86 \\
114 / 72\end{array}$ & $\begin{array}{l}0.18 \\
0.22 \\
0.16 \\
0.12 \\
0.28 \\
0.26 \\
0.21 \\
0.14 \\
0.16 \\
0.23\end{array}$ & $\begin{array}{r}153 \\
99 \\
147 \\
183 \\
108 \\
93 \\
121 \\
168 \\
186 \\
114\end{array}$ \\
\hline J.G. & $\mathbf{5 0} \mathbf{M}$ & Atypical; second & Equivocsl & Ootober 31, 19419 & November 11, 1941 & Unknown & $110 / 68$ & $110 / 80$ & $98 / 56$ & 0.29 & 74 \\
\hline $\begin{array}{l}\text { D.R. } \\
\text { B.K. } \\
\text { B.8. } \\
\text { B.M. }\end{array}$ & $\begin{array}{l}39 \mathrm{M} \\
48 \mathrm{M} \\
64 \mathrm{M} \\
55 \mathrm{M}\end{array}$ & $\begin{array}{l}\text { Atypioal } \\
\text { Typical } \\
\text { Typioal } \\
\text { Atypioal }\end{array}$ & $\begin{array}{l}\text { Equivocal } \\
\text { Progresive change } \\
\text { Progreesive change } \\
\text { Progreadive change }\end{array}$ & $\begin{array}{l}\text { Ootober 1, 1941? } \\
\text { July 5, 1940 } \\
\text { May 6, 1936 } \\
\text { February 19, } 1941\end{array}$ & $\begin{array}{l}\text { November 3, } 1941 \\
\text { November 24, } 1941 \\
\text { November 14, } 1941 \\
\text { November 16, } 1941\end{array}$ & $\begin{array}{l}150 / 9 \\
\text { Normal } \\
140 / 90 \\
150 / 110\end{array}$ & $\begin{array}{l}130 / 88 \\
125 / 88 \\
155 / 95 \\
142 / 98\end{array}$ & $\begin{array}{l}142 / 94 \\
116 / 84 \\
138 / 90 \\
138 / 84\end{array}$ & $\begin{array}{r}118 / 84 \\
92 / 78 \\
115 / 80 \\
120 / 82\end{array}$ & $\begin{array}{l}0.18 \\
0.34 \\
0.24 \\
0.26\end{array}$ & $\begin{array}{r}159 \\
69 \\
114 \\
111\end{array}$ \\
\hline
\end{tabular}

tack, where that could be determined. The resistance was elevated in twenty cases and normal in six. In seventeen of the twenty cases in which it was elevated, the previous blood pressure was known to be high, either from the hospital records or from the patient's statement. The correlation between the level of the resistance and the level of the previous blood pressure was accurate in some cases and only fairly accurate in others, a discrepancy ascribable to errors in measuring blood pressure and to fluctuations in the neurogenic complement of the hypertension. Of the six cases with normal digital vascular resistance, the previous blood pressure was known to be normal in two and unknown in three. In the remaining case (G. L.), the antecedent blood pressure was known by the patient to be high. This patient, however, was psychoneurotic and her blood pressure fluctuated widely under observation. The basal level, therefore, may well have been normal in this case.

In all the cases of acute myocardial infarction in which the digital blood flow was decreased, the brachial and digital blood pressures were below the level of the previous blood pressures and below the level to be expected from that of the vascular resistance. Many of these blood pressures, however, at face value, appeared normal. It is apparent, therefore, that the decrease in blood flow was proportional to the decrease in blood pressure, the vascular resistance remaining essentially unchanged. In those cases, on the other hand, in which the digital blood flow was normal (doubtful and old cases), the brachial and digital blood pressure levels were in accord with previous blood pressure levels and with the vascular resistances.

\section{COMMENT}

\section{Discussion of methods}

Many attempts have been made to measure the peripheral resistance in normal subjects and in patients with hypertension. These studies have been of two main varieties. In the first, the general systemic peripheral resistance is calculated from the left ventricular output and the brachial arterial blood pressure; whereas in the second, 
the local vascular resistance in a part of the systemic circulation, such as the forearm or hand, is calculated from the blood pressure in the local artery and the blood flow per unit of tissue.

Calculation of the general systemic vascular resistance from the cardiac output and the aortic blood pressure depends upon accurate measurement. The relatively accurate Fick (10) and acetylene (11) methods are time-consuming and too disturbing for use in seriously ill patients. The more indirect methods, such as the ballistocardiographic technique (12) and the methods of Böger and Wezler (4) and of Bazett, Cotton, Laplace and Scott (5), are fairly accurate when applied to normal subjects but introduce considerable error, especially in the abnormal patient. The use of the brachial arterial blood pressure to indicate pressure in the ascending aorta may also introduce some error, especially in the presence of circulatory disturbances. In addition, as pointed out by Wiggers (13), the measurement of systemic vascular resistance by these techniques includes the variable of resistance in the large arteries as well as the more important variable of arteriolar resistance. Although it is true that it is the total peripheral resistance which determines the level of the blood pressure rather than the resistance in the terminal arterioles alone, changes in the latter are agreed to be of more fundamental importance in hypertension and might therefore be better measured separately.

The methods hitherto employed to measure local blood flow, blood pressure, and vascular resistance have also been unsatisfactory. One of the methods ordinarily used to measure blood flow quantitatively is the plethysmographic. The most important difficulty encountered with this method has been the enormously wide normal range of variation in blood flow per unit of tissue. In the plethysmographic studies of Prinzmetal and Wilson (14), this range was particularly wide since these authors did not take the precaution of shutting off the more labile circulation of the hand (15). The normal resting blood flow varied from 1.75 to $7.0 \mathrm{cc}$. per $100 \mathrm{cc}$. of tissue per minute; whereas, after release of sympathetic tone by body warming, it varied from 2.3 to $10.1 \mathrm{cc}$. per 100 cc. per minute. Abramson (16) took the precaution of excluding hand blood flow but measured only the resting blood flow, and con- cluded that it was greater in patients with hypertension than in normal subjects. The normal range of variation was from 0.9 to $3.3 \mathrm{cc}$. per 100 cc. per minute, and in hypertension from 1.4 to $4.0 \mathrm{cc}$. per $100 \mathrm{cc}$. per minute. The wide normal range of variation in resting blood flow, due, at least in part, to variations in vasomotor nerve tone, makes it very difficult to evaluate deviations from the normal because of overlapping. Wilkins and Eichna (17) found a normal range of from 2.3 to $7.0 \mathrm{cc}$. per $100 \mathrm{cc}$. per minute, even after taking the precaution of warming the body and of measuring only forearm blood flow by shutting off the circulation to the hand. In the foot, Stead and Kunkel (18) found the normal range to be from 14.0 to $34.0 \mathrm{cc}$. per $100 \mathrm{cc}$. per minute after vasodilatation by body warming and local heat. These wide normal ranges of variation are probably attributable to the limitations of the Hewlett and van Zwaluwenburg technique (19) of measuring blood flow plethysmographically after venous occlusion. The possible sources of error are incomplete venous obstruction because of venous flow through the bones, and variable proportion of bone to muscle and skin mass. In addition, the rising venous pressure after venous obstruction produces a progressively smaller effective mean arterial pressure even in the presence of an unchanging brachial arterial blood pressure. Since it is extremely difficult technically to measure this effect, another variable error is introduced, especially if vascular resistance is to be measured. Similar objections can be made to the digital plethysmograph (20) except that the technical difficulties here are even more formidable.

Pickering (21) considered heat elimination in the hand calorimeter to be proportional to blood flow, but also found a wide normal range of variation even after body warming. The most important sources of error in the hand calorimeter are the discrepancy between venous blood temperature and calorimeter temperature (22), and the use of volume instead of surface for tissue units (23).

In the finger tip calorimeter the variation between actual venous blood temperature and calorimeter temperature is minimal (1), probably because almost the entire blood flow is through the surface vessels. The ease of measuring the surface of the finger tip and the expression of the 
digital blood flow in terms of surface rather than volume also eliminate an important source of error. With this method, therefore, the normal range of variation in blood flow $(0.23$ to $0.34 \mathrm{cc}$. per sq. $\mathrm{cm}$. per minute) is much narrower than with any of the other methods. The blood pressure to the terminal digit, moreover, can be measured directly and need not be inferred from the brachial blood pressure. In addition, there are no abnormal constrictions and the effective mean pressure can be calculated from the arterial pressure and the normal or abnormal venous pressure.

The digital calorimetric method for measuring blood flow, together with all local methods, has the disadvantage of measuring the status of a small portion of the systemic circulation rather than that of the circulation in general. The results are therefore difficult to interpret in the presence of conditions affecting the local circulation, such as scleroderma or clubbing. Another disadvantage is the measurement of the circulation under unusual conditions, namely, after vasodilatation by body warming. Normal digital blood flow, however, is defined by measurement under the same circumstances, and since the normal range of variation in blood flow is narrowed extremely by preliminary body warming, this procedure becomes indispensable for interpreting deviations from the normal. Without it, the overlapping of the normal range by the abnormal would make it impossible to distinguish one from the other. It is sufficient, therefore, for comparative purposes if the digital circulation studied in this way mirrors the systemic circulation in general, which, in the absence of local disease of the fingers, we have reason to believe it does.

\section{Discussion of results}

It can be seen from Table II that after vasodilatation by body warming, the digital circulation of patients with neurogenic elevations of blood pressure is indistinguishable from that of normal subjects. In fact, it is probable that these patients are entirely normal, except for a tendency to neurogenic vasoconstriction in response to certain stimuli. By measuring the digital circulation after body warming, it is possible to distinguish a neurogenic and probably transient elevation of blood pressure from one which is fixed. Since neurogenic vasoconstriction may also be observed in cases of true essential or renal hypertension, study of the digital circulation in these cases makes it possible to determine how much of the elevation of blood pressure is neurogenic and how much is fixed.

It is difficult to draw definite conclusions from the small number of observations made in acute glomerulonephritis and in early essential hypertension. The decrease in blood flow found in these cases, however, is evidence in favor of the view that an increase in fixed resistance is the primary process in these diseases. Hypertrophy of the heart may lag behind and eventually cause a further rise in blood pressure and a restoration of the blood flow to within normal limits in the more advanced stages of essential or renal hypertension. In the malignant phase, the hypertrophied heart can probably no longer keep pace with the further increase in resistance by equivalent elevation of the blood pressure, and the blood flow again decreases. It is apparent, therefore, that only in established essential or renal hypertension is the blood pressure an adequate index of the peripheral resistance. In the acute or malignant phase, the actual resistance may be considerably greater than is indicated by the blood pressure level. It should also be noted that the increase in fixed resistance in acute glomerulonephritis is reversible.

From Table III, it is apparent that a decreased digital blood flow is a consistent finding in the first six weeks after a coronary occlusion. This phenomenon was observed in several cases in which the electrocardiograms were equivocal, although the clinical course was characteristic of coronary occlusion. In the doubtful cases, in which both the clinical course was atypical and the electrocardiograms inconclusive, it is probable that the demonstration of a decreased digital blood flow indicated the presence of an acute myocardial infarct.

Since it is possible, on the other hand, for the blood flow to be within normal limits in an occasional case of acute coronary occlusion, the demonstration of a normal digital blood flow cannot be considered absolute evidence of the absence of acute myocardial infarction. In addition, a decrease in digital blood flow is demonstrable only 
in the first six weeks, or perhaps in some cases, few months after the onset of the acute occlusion; for in cases studied several months or more after the acute coronary thrombosis, the digital blood flow was within normal limits. It should also be pointed out that a decrease in digital blood flow is not pathognomonic of coronary occlusion. Such decreases occur in acute and malignant hypertension, in various peripheral vascular diseases and also in systemic conditions associated with shock. Studies of the digital circulation alone in such cases would be difficult to interpret, although they might render valuable information, especially if concomitant measurements of blood volume and other aspects of the circulation were made. The demonstration of decreased digital blood flow can be helpful, however, in the differentiation of a genuine case of coronary thrombosis from angina pectoris.

The correlation between the digital vascular resistance as measured after acute coronary occlusion and the antecedent blood pressure level makes it possible to determine the presence or absence of preëxisting hypertension. The determination of the digital vascular resistance thus offers a method of measuring the extent of the fundamental vascular abnormality in hypertension, even when complicating factors have reduced the blood pressure.

From these studies, the probable mechanism of the circulatory changes produced by an acute coronary occlusion may be visualized as follows: A decrease in myocardial contractile force is produced by the infarction. This operates against an unchanged vascular resistance or a resistance increased by compensatory vasoconstriction to bring about a decrease in arterial blood pressure. The decrease in arterial blood pressure is not, in other words, caused by a decrease in resistance, but largely by a decrease in the cardiac driving force. The decrease in arterial blood pressure, together with such compensatory vasoconstriction as takes place, causes a decrease in systemic blood flow, venous return, and cardiac output. This produces a further decrease in blood pressure. The process, therefore, is probably one of progressive deceleration of the circulation, ultimately balanced at a lower equilibrium by those forces which tend to keep the blood flow normal.

\section{SUMMARY AND CONCLUSIONS}

1. Methods for calculating the digital blood flow from calorimetric observations have been modified and a method developed for calculating digital vascular resistance.

2. After vasodilatation produced by warming the body, normal digital blood pressure, blood flow, and vascular resistance were found in patients with neurogenic elevations of blood pressure. A consistent increase in digital vascular resistance and a normal digital blood flow were demonstrated in established essential or renal hypertension. In acute and in malignant hypertension, the digital blood flow may be decreased, and the vascular resistance increased out of proportion to the elevation in blood pressure.

3. Decrease in digital blood flow and blood pressure, and unchanged vascular resistance were demonstrated in cases of acute coronary occlusion, whether the antecedent blood pressure was normal or elevated.

This opportunity is taken of acknowledging the cooperation of Drs. B. S. Oppenheimer, G. Baehr, E. Moschcowitz, and E. P. Boas in making these cases available for study, and of Dr. A. M. Master, in whose department some of these studies were carried out.

\section{BIBLIOGRAPHY}

1. Mendlowitz, M., Measurements of blood flow and blood pressure in clubbed fingers. J. Clin. Invest., 1941, 20, 113.

2. Mendlowitz, M., Schauer, G., and Gross L., Hemodynamic studies in experimental coronary occlusion. III. Denervated heart experiments. Am. Heart J., 1937, 14, 21.

3. Stewart, G. N., Blood flow in the hand, normal and pathological. Harvey Lectures, 1912, 8, 86.

4. Böger, A., and Wezler, K., Die Bestimmung des arteriellen Gesamtwiderstandes am Menschen. Arch. f. exper. Path. u. Pharmakol., 1937, 186, 43.

5. Bazett, H. C., Cotton, F. S., Laplace, L. B., and Scott, J. C., The calculation of cardiac output and effective peripheral resistance from blood pressure measurements with an appendix on the size of the aorta in man. Am. J. Physiol., 1935, 113, 312.

6. Whittaker, S. R. F., and Winton, F. R., The apparent viscosity of blood flowing in the isolated hind limb of the dog and its variation with corpuscular concentration. J. Physiol., 1933, 78, 339.

7. Gaertner, G., Uber einen neuen Blutdruckmesser (Tonometer). Wien. klin. Wchnschr., 1899, 12, 696. 
8. Von Recklinghausen, H., Unblutige Blutdruckmessung. Arch f. exper. Path. u. Pharmakol., 1906, 55, 375.

9. Fishberg, A. M., Heart Failure. Lea and Febiger, Philadelphia, 1940, 2nd edition, p. 456.

10. Fick, A., Ueber die Messung des Blutquantums in den Herzventrikeln. Verh. d. PhysikalischMedizinischen Gesellschaft zu Wurzburg, 1870, 2, 16.

11. Grollman, A., The Cardiac Output of Man in Health and Disease. Charles C. Thomas, Springfield, Ill., 1932.

12. Starr, I., Rawson, A. J., Schroeder, H. A., and Joseph, N. R., Studies on estimation of cardiac output in man, and of abnormalities in cardiac function, from heart's recoil and blood's impacts; ballistocardiogram. Am. J. Physiol., 1939, 127, 1.

13. Wiggers, C. J., Basic hemodynamic principles essential to interpretation of cardiovascular disorders. Bull. N. Y. Acad. Med., 1942, 18, 3.

14. Prinzmetal, M., and Wilson, $C$., The nature of the peripheral resistance in arterial hypertension with special reference to the vasomotor system. J. Clin. Invest., 1936, 15, 63.

15. Grant, R. T., Observations on blood circulation in voluntary muscle in man. Clin. Sc., 1938, 3, 157.
16. Abramson, D. I., Resting peripheral blood flow in hypertensive subjects. Proc. Soc. Exper. Biol. and Med., 1940, 45, 127.

17. Wilkins, R. W., and Eichna, L. W., Blood flow to the forearm and calf. Bull. Johns Hopkins Hosp., 1941, 68, 425.

18. Stead, E. J., Jr., and Kunkel, P., The nature of peripheral resistance in arterial hypertension. $J$. Clin. Invest., 1940, 19, 25.

19. Hewlett, A. W., and van $Z$ waluwenburg, J. G., The rate of blood flow in the arm. Heart, 1909, 1, 87.

20. Wilkins, R. W., Doupe, J., and Newman, H. W., The rate of blood flow in normal fingers. Clin. Sc., 1938, 3, 403.

21. Pickering, G. W., The peripheral resistance in persistent arterial hypertension. Clin. Sc., 1936, 2, 209.

22. Harris, K. E., and Marvin, H. M., A note on the temperature of venous blood and its use in estimating rate of blood flow to the hand. Heart, 1927, 14, 49.

23. Mendlowitz, M., Clubbed fingers and hypertrophic osteoarthropathy. Medicine, 1942. (In press.) 